\title{
Ten-year trends in atmospheric mercury concentrations, meteorological effects and climate variables at Zeppelin, $\mathrm{Ny}$-Ålesund
}

\author{
T. Berg ${ }^{1}$, K. A. Pfaffhuber ${ }^{2}$, A. S. Cole ${ }^{3}$, O. Engelsen ${ }^{2}$, and A. Steffen ${ }^{3}$ \\ ${ }^{1}$ Department of Chemistry, Norwegian University of Science and Technology (NTNU), Gløshaugen, 7491 Trondheim, \\ Norway \\ ${ }^{2}$ Norwegian Institute for Air Research (NILU), P.O. Box 100, 2027 Kjeller, Norway \\ ${ }^{3}$ Air Quality Processes Section, Environment Canada, 4905 Dufferin St., Toronto, Ontario, M3H 5T4, Canada
}

Correspondence to: (torunn.berg@chem.ntnu.no)

Received: 5 October 2012 - Published in Atmos. Chem. Phys. Discuss.: 22 January 2013

Revised: 4 June 2013 - Accepted: 10 June 2013 - Published: 11 July 2013

Abstract. Results from ten years of gaseous elemental mercury (GEM) measurements at Zeppelin station, Ny-Ålesund, Svalbard, show no overall annual trend between 2000 and 2009. Seasonal trend analysis showed significantly decreasing trends in January, February, March and June ( -4.5 to $-14.9 \mathrm{pg} \mathrm{m}^{-3} \mathrm{yr}^{-1}$ ) and significantly increasing trends in May and July through December (1.5 to $28.7 \mathrm{pg} \mathrm{m}^{-3} \mathrm{yr}^{-1}$ ). Results showed that atmospheric mercury depletion events (AMDEs) were equally distributed between April and May with only a few having been observed in March and June. A negative correlation between AMDEs and temperature is reported and supports earlier observations that AMDEs tend to occur at low temperatures. Lower concentrations of GEM were seen at lower temperatures below a threshold of $0^{\circ} \mathrm{C}$. The occurrence of AMDEs and wind direction were well correlated with the lowest GEM measured when the wind direction was from the Arctic Ocean region. Wind speed was found to not correlate with AMDEs, but the lowest GEM concentrations were observed at low wind speeds between 4 and $11 \mathrm{~m} \mathrm{~s}^{-1}$. AMDEs and relative humidity did not correlate well, but the lowest GEM levels appeared when the relative humidity was between 80 and $90 \%$. Diurnal variation was observed especially during the month of March and is probably due to daytime snow surface emission induced by solar radiation. Relationships between GEM concentration and the Northern Hemisphere climate indices were investigated to assess if these climate parameters might reflect different atmospheric conditions that enhance or reduce spring AMDE activity. No consistent pattern was observed.

\section{Introduction}

Mercury $(\mathrm{Hg})$ is a major pollutant in the Arctic environment, and there is evidence of increasing concentrations in some marine ecosystems over time (AMAP, 2011). The presence of $\mathrm{Hg}$ in traditional foods contributes to increasing concern about food safety for the Arctic's indigenous people. Atmospheric $\mathrm{Hg}$ is recognized as one of the main sources to the environment and particular attention has been paid to understand the importance of atmospheric mercury depletion events (AMDE) as a means of delivering $\mathrm{Hg}$ to polar ecosystems (AMAP, 2011).

$\mathrm{Hg}$ in the atmosphere exists in a variety of forms as gaseous elemental mercury (GEM or $\mathrm{Hg}^{\circ}$ ), gaseous oxidized mercury (GOM) and particle bound mercury (PBM). Current estimates of the atmospheric residence time of GEM range from months up to $1 \mathrm{yr}$ (Hedgecock and Pirrone, 2004; Selin et al., 2007; Corbitt et al., 2011) and is considerably longer than the residence time of GOM and PBM which can be deposited within hours to weeks (Schroeder and Munthe, 1998).

In 1995 it was discovered that during spring, unexpectedly low concentrations of GEM occurred in the Arctic air (Schroeder et al., 1998). These phenomena were termed AMDEs (Schroeder et al., 1998), and were later confirmed to occur throughout polar regions at Barrow, Alaska (Lindberg et al., 2002); Ny-Ålesund, Svalbard (Berg et al., 2003); Kuujjuarapik, Quebec (Poissant, 2003); Station Nord, Greenland (Skov et al., 2004); Amderma, Russia (Steffen et al., 2005); Andøya (Berg et al., 2008b) and Antarctica (Ebinghaus et al., 
2002; Pfaffhuber et al., 2012). During AMDEs a series of photochemically initiated reactions involving halogens convert GEM to more reactive mercury species that subsequently associate to particles in the air and/or deposit to the polar environment (Steffen et al., 2008 and references therein). The halide species (e.g. $\mathrm{Cl}, \mathrm{Br}, \mathrm{ClO}, \mathrm{BrO}$ ) are derived from heterogeneous gas/solution reactions at the interface of hygroscopic sea salt aerosols, which are initiated in the oceans (Simpson et al., 2007; Steffen et al., 2008).

Worldwide atmospheric mercury measurements up to the early 2000s suggested that GEM levels increased from the late 1970s to a peak in the 1980s and decreased and plateaued from 1996 to 2001 (Slemr et al., 2003). At Mace Head, air masses that have traversed the North Atlantic Ocean have shown a decrease in the total gaseous mercury (TGM) concentrations by $-0.028 \pm 0.01 \mathrm{ng} \mathrm{m}^{-3} \mathrm{yr}^{-1}$ for the period 1996-2009 (Ebinghaus et al., 2011). Long-term atmospheric mercury monitoring data of GEM in polar regions are rare; however GEM has been measured at Alert, Canada, since 1995. A trend analysis of the data showed a decreasing trend of $-0.0086 \mathrm{ng} \mathrm{m}^{-3} \mathrm{yr}^{-1}$ for the 1995-2007 period (Cole and Steffen, 2010). Earlier time trend analyses on the $\mathrm{Hg}$ data from Zeppelin have also been conducted over several time periods. For the period 1994 to 2002, and again 1995 to 2005, Berg et al. $(2004,2008$ a) reported no trends for GEM concentrations. In both these studies manually collected data for 1994-1999 were included. In the former study annual averages were analysed, and in the latter study, annual, winter, spring, summer and autumn means were used.

Intensive measurement campaigns designed to understand the cycling of atmospheric mercury provide considerable information which apply only a snapshot in time. Care should be taken when scaling-up such measurements to apply for longer time periods and over large geographical areas (Pfaffhuber et al., 2012). Long-term measurement programs can provide valuable information towards understanding the processes involved in the cycling of $\mathrm{Hg}$ in the polar atmosphere. These observations are also important for addressing potential effects of climate warming on the mercury cycle. Additionally, long-term observations are needed to see possible effects from changes in the global anthropogenic $\mathrm{Hg}$ emissions on the deposition of $\mathrm{Hg}$ to the polar regions (Steffen et al., 2008).

In the present manuscript, trend analysis of GEM has been carried out to see if there was a change in the concentrations from 2000 to 2009. The changes in trends have also been studied for each month. Additionally, the relationships between AMDEs and different meteorological data, UV radiation and climate parameters have been examined.

\section{Methods}

\subsection{Study site}

Ny-Ålesund is a small settlement near sea level on the western coast of Spitsbergen (Fig. 1). Air sampling is performed at the research station on the nearby Zeppelin Mountain $\left(78^{\circ} 54^{\prime} \mathrm{N}, 11^{\circ} 52^{\prime} \mathrm{E} ; 474 \mathrm{~m}\right.$ a.s.1.). The station is located on a mountain ridge, with steep hills to the north and south, and higher mountain peaks (1000-1500) to the west and east. The mountain station was situated as such to minimize the influence of local pollution from the $\mathrm{Ny}$-Ålesund area.

\subsection{Sampling}

Measurements of GEM were carried out using a Tekran gas phase mercury analyser (model Tekran 2537A, Tekran Inc.) (Berg et al., 2003). The basic principle of operation is that the sample air stream is pulled through gold cartridges where GEM is collected. GEM is then thermally desorbed and detected by cold vapour atomic fluorescence spectroscopy (CVAFS). The Tekran 2537 was set up with a heated sampling line and an extra Teflon filter $(2 \mu \mathrm{m}, 47 \mathrm{~mm})$ at the inlet of the sampling line. A soda lime trap was also installed in line before the instrument filter. Due to the presence of two filters and the soda lime trap the measurements represent GEM and very little or no GOM (Steffen et al., 2002). The soda lime trap was changed every two weeks. The sample inlet was located 3 metres above ground. Auto calibrations were carried out daily using the internal calibration source and were verified by manual injections every $3-4$ months. A sampling flow rate of $1.5 \mathrm{~L} \mathrm{~min}^{-1}$ and a sampling time of $5 \mathrm{~min}$ were used. The 5 min means were averaged to hourly or daily means. The detection limit of the Tekran $2537 \mathrm{~A}$ is $<0.1 \mathrm{ng} \mathrm{m}^{-1}$, and the precision was found to be within 5\% (Aspmo et al., 2005). The Tekran 2537A provide volumes at $0^{\circ} \mathrm{C}$ and $760 \mathrm{~mm}$ Hg (Tekran Inc., 1998). An atmospheric depletion episode is defined in this study as GEM concentrations below $1.0 \mathrm{ng} \mathrm{m}^{-3}$ (Cobbett et al., 2007).

Hourly meteorological data from the Zeppelin station (including temperature, wind direction, wind speed, relative humidity and atmospheric pressure) were provided by the Norwegian Institute for Air Research (NILU). Precipitation data was provided from the Norwegian Meteorological Institute's measurements in Ny-Ålesund.

Measurements of UV erythemal hourly dose rates were obtained from the ground-based ultraviolet radiometer (GUV, Biospherical Instruments Inc.) on top of the Sverdrup station in the Ny-Ålesund settlement at $25 \mathrm{~m}$ a.s.l. Applying the libRadtran simulation package (Mayer and Kylling, 2005), the erythemal UV measurements were transformed to the corresponding UVB and CRS03 hourly dose rates on top of the Zeppelin mountain station ( $474 \mathrm{~m}$ a.s.l.) assuming the same ozone and cloud conditions for both measurement elevations at this pristine Arctic location. The CRSO3 


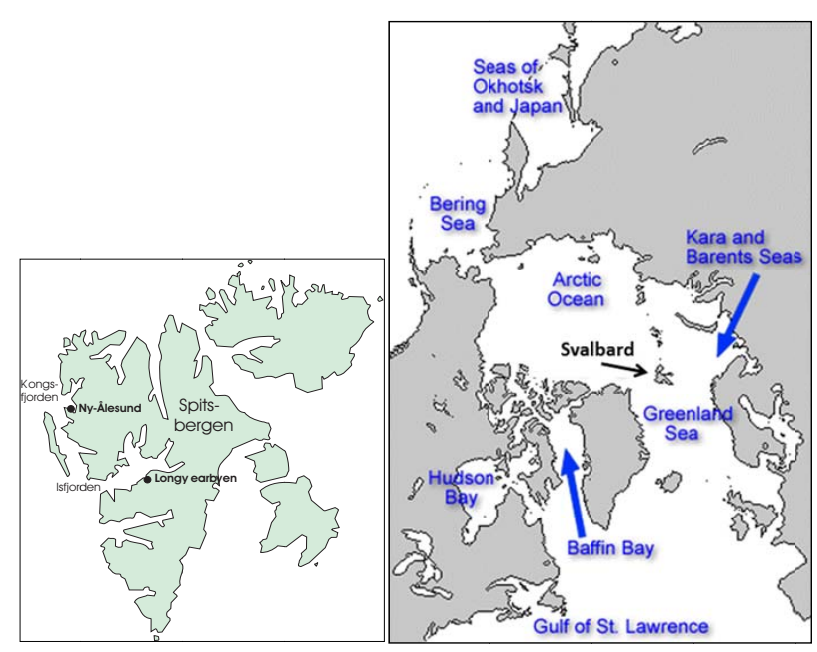

Fig. 1. Map showing Ny-Ålesund, Svalbard (left), and the sea ice regions (right).

dose rates were computed using the wavelength-dependent ozone absorption cross sections (Molina and Molina, 1986) as action spectrum. The erythemally effective UV dose rates were converted to UVB dose rates because UVB radiation seems related to Hg measurements (Lindberg et al., 2002). The CRSO3 and UVB dose rates were applied as proxys for photolysis rates.

Monthly sea ice area index and maps for the Northern Hemisphere were obtained from the National Sea Ice Data Center (Fetterer et al., 2002, updated 2012). Monthly values of standard Northern Hemisphere teleconnection indices were obtained from the National Weather Service Climate Prediction Center (Fetterer et al., 2002, updated 2012).

\subsection{Statistics}

The trend analysis was carried out using the seasonal Kendall test for trend (a variant of the Mann-Kendall test) and the related Sen's slope estimator (Gilbert, 1987). In the seasonal Kendall test, each month is treated as a separate data set and twelve Mann-Kendall tests are performed. For the GEM data, each hourly data point was treated as a replicate point for that month and year. The Sen's calculation of slope was then performed to give an estimate of the linear slope for that month (the median of millions of slopes between each hourly pair) and its uncertainty, resulting in trends of different magnitudes and directions in all the months. If seasonal trends were homogenous, the results were used to determine an overall trend for the period. Otherwise, less precise but homogenous seasonal trends and the overall trend were calculated using monthly median GEM.

GEM concentrations during and after the active AMDE period (February to June) were also compared to meteorological parameters at the Zeppelin station. For this analysis, hourly concentrations in a given month were binned accord- ing to a corresponding hourly meteorological parameter such as temperature or wind speed. Within each bin, summary statistics were calculated for the hourly GEM values as long as the bin contained at least 20 hourly GEM values.

Finally, correlation coefficients for monthly median GEM concentrations, average monthly meteorological values, and monthly climate indices were calculated using the Statistica software program.

\section{Results and discussion}

The GEM concentration data from the Ny-Ålesund, Zeppelin station for the period 2000-2009 is presented as a monthly box and whisker plots in Fig. 2. The arithmetic mean and median for the data set were $1.54 \pm 0.23$ and $1.60 \mathrm{ng} \mathrm{m}^{-3}$, respectively. This is in agreement with the average concentrations for the Northern Hemisphere, $1.5-1.7 \mathrm{ng} \mathrm{m}^{-3}$ proposed by Slemr et al. (2003), but significantly higher than GEM concentrations in the Southern Hemisphere, as evidenced by the annual mean concentration of $0.93 \mathrm{ng} \mathrm{m}^{-3}$ at the Norwegian station Troll in Antarctica from 2007 to 2011 (Pfaffhuber et al., 2012). The monthly median concentrations show the seasonal behaviour of mercury at this site. GEM is higher than the mean during late fall, winter and early spring. This is the time of the year when the measured air masses at this location are dominated by transport from mid latitude source regions (Hirdman et al., 2009). As expected, April and May reflect the lowest GEM concentrations due to the AMDEs and are below the annual mean. During summer the concentrations increase due to the re-emission of previously deposited GEM (Hirdman et al., 2009). In late summer the GEM concentrations start to decrease again and by fall the levels are approximately at the global background for the Northern Hemisphere.

\subsection{Trends in atmospheric GEM}

The time series of GEM daily average concentration between 2000 and 2009 is presented in Fig. 3. No significant annual trend for the GEM data from Zeppelin between 2000 and 2009 was found. This trend analysis was conducted using annual concentration changes calculated using the Sen's slope estimate (based on the seasonal Kendall test for trend) within both the 90 and $95 \%$ confidence levels (Fig. 3). The lack of an annual trend in the median GEM concentration for this time period is in agreement with earlier trend analyses for $\mathrm{Hg}$ at this location. These previous studies found no significant changes in the GEM levels between 1994 and 2002 (Berg et al., 2004) or the period of 1994 to 2005 (Berg et al., 2008a). In both previous studies manually collected data were included for 1994 to 1999 whereas this study did not include these manually collected data. The 2004 study employed the non-parametric Mann-Kendall test and the Sen's slope estimator on annual weighted means. The 2008 study 


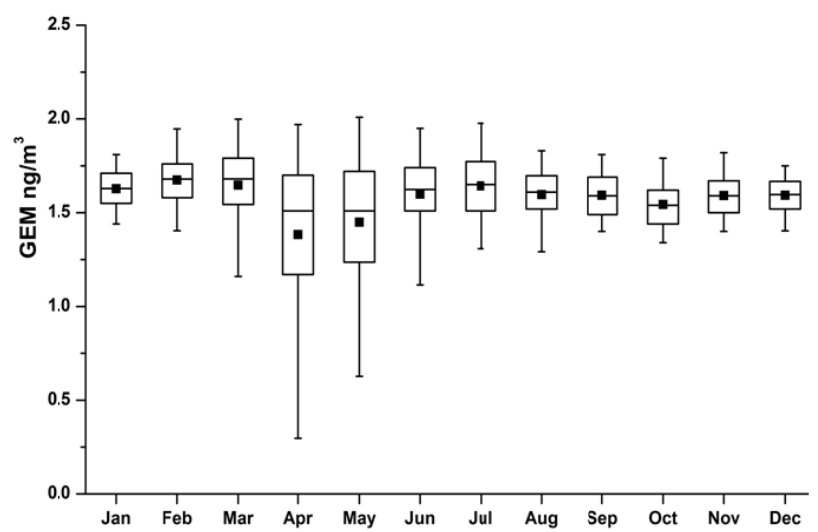

Fig. 2. Box and whisker plot presenting the concentration distribution of GEM measurements at Zeppelin. The middle line in the box shows the median concentrations, the box indicates the range between the 25 th and the 75 th percentiles. Whiskers above and below the box indicate the 90th and 10th percentiles respectively. The filled square shows the arithmetric mean.

used the same test on the annual, winter, spring, summer and autumn weighted means. The manually collected data was not included in the present trend analysis because the data coverage was not sufficient for some of the statistical analysis and the measurements were collected using different methods. This was done to assess if these differences reflected a change in the trend analysis.

In the present study, the results of the seasonal Kendall test (using hourly data points) showed significant trends in every month with a $95 \%$ confidence level. The Sen's calculation of slope was then performed to give an estimate of the linear slope for each month and this showed both trends of different magnitudes and directions for each month (Fig. 4). A negative slope indicates a decreasing trend in the concentration of GEM during that particular month over the 2000-2009 period. Additionally, a positive slope represents an increasing trend for a given month. As seen in Fig. 4, most months show increasing trends at the Zeppelin station. April, May and August through December showed significant increasing trends with the highest seen in May $\left(28.7 \pm 1.6 \mathrm{pg} \mathrm{m}^{-3} \mathrm{yr}^{-1}\right)$. Some of the months including January, March and June show decreasing trends with the largest reported from February $\left(-14.9 \pm 1.7 \mathrm{pg} \mathrm{m}^{-3} \mathrm{yr}^{-1}\right)$.

The lack of a significant annual decreasing or increasing trend is in contrast to what has been reported for other sampling sites. A weak decreasing trend of $-0.0086 \pm 0.0014 \mathrm{ng} \mathrm{m}^{-3} \mathrm{yr}^{-1}\left(-0.56 \% \mathrm{yr}^{-1}\right)$ was reported for the Arctic station Alert for the period of 1995 to 2007 (Cole and Steffen, 2010). At Mace Head, Ireland, a stronger decreasing trend of $-0.028 \pm 0.01 \mathrm{ng} \mathrm{m}^{-3} \mathrm{yr}^{-1}$ $\left(1.6-2 \% \mathrm{yr}^{-1}\right)$ was reported for the period of 1996 to 2009 (Ebinghaus et al., 2011). Several reasons for the reported weak or insignificant trends in the high Arctic GEM (Alert

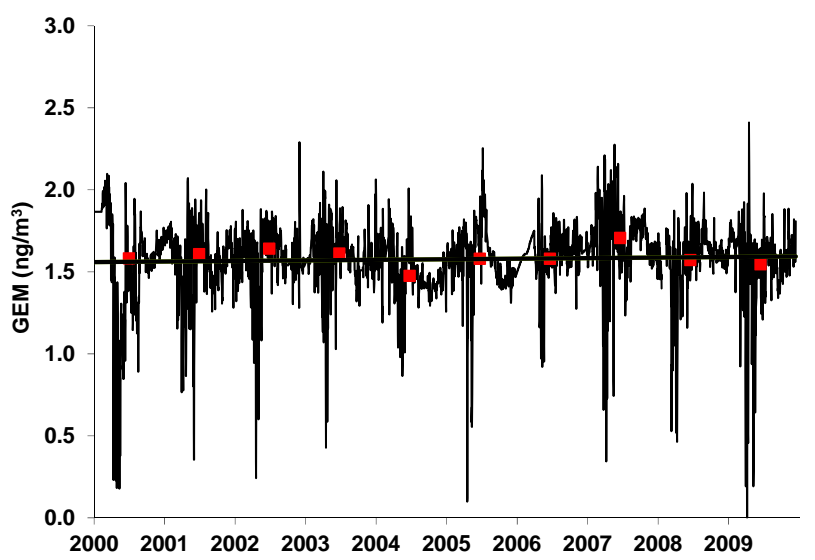

Fig. 3. The time series for GEM daily average levels including the trend line. The trend line is based on the overall slope from the trend analysis with the midpoint fixed to the median concentrations for the decade. Red squares are annual medians.

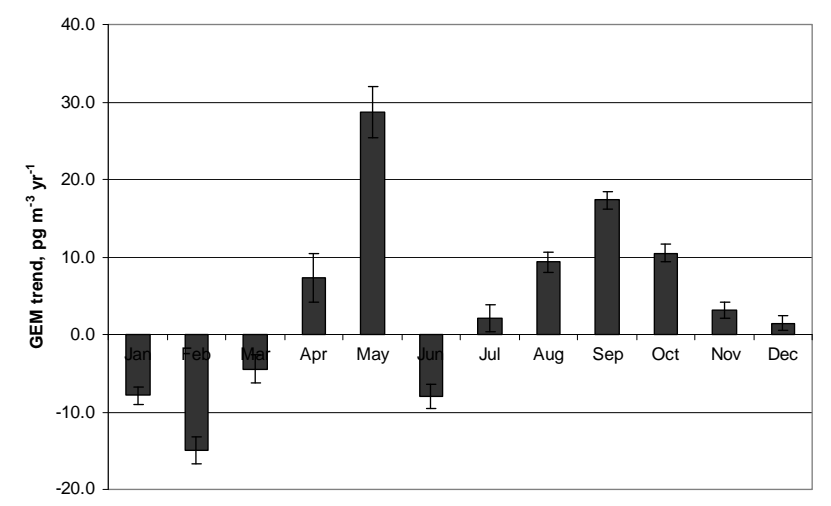

Fig. 4. Seasonal (monthly) trends in GEM base on daily average measurements 2000-2009. Error bars represent $95 \%$ confidence limits.

and Zeppelin) when compared to Ireland have been discussed in detail in Cole et al. (2013). Briefly, most of the available GEM concentration measurements begin after 1995 (Berg et al., 2004, 2008a; Cole and Steffen, 2010) since which total global anthropogenic emissions of $\mathrm{Hg}$ have increased a little, although there have been significant changes in emissions from particular source regions during this period. This statement is according to the newest, recalculated and updated emission estimates for 1995, 2000, 2005 and 2010 (AMAP/UNEP, 2013; Pacyna et al., 2010). Mercury emissions from East Asia have increased by $50 \%$ from 1990 to 2005 whereas emissions from Europe and North America have declined over the same period and estimates for 2010 show a further increase from East Asia (AMAP/UNEP, 2013). Overall, these emission trends are smaller compared to those reported from the 1970s and 1980s (Pacyna et al., 2009). While emission source region amounts have shifted, GEM concentrations at Zeppelin station have not 
and are known to be impacted by European emissions and not by direct transport from South East Asia (Hirdman et al., 2009). The decrease in GEM in January, February and March at Zeppelin reflects winter European emission reductions (Hirdman et al., 2009). The long-term trends observed in the Arctic can also be controlled by trends in transport/circulation patterns that influence the air masses that reach the Arctic (Kahl et al., 1999). The lack of a decreasing trend, in contrast to Mace Head and other midlatitude sites, could also be due to enhanced evasion of GEM from the Arctic sea ice regions, due to decreases in ice cover (Fetterer et al., 2002, updated 2012). During a summer expedition in the North Atlantic, GEM showed a homogeneous distribution over the open North Atlantic (median $1.53 \pm 0.12 \mathrm{ng} \mathrm{m}^{-3}$ ) but higher concentrations over the sea ice (median $1.82 \pm 0.24 \mathrm{ng} \mathrm{m}^{-3}$ ) (Aspmo et al., 2006).

The seasonal trend analysis for Alert (1995-2007) showed decreasing trends in all months except for May which showed a positive trend (Cole and Steffen, 2010). In contrast, this study found that, at Zeppelin, only January-March and June showed decreasing trends $\left(-4.5\right.$ to $\left.-14.9 \mathrm{pg} \mathrm{m}^{-3} \mathrm{yr}^{-1}\right)$ while the remainder of the year shows increasing trends (1.5 to $28.7 \mathrm{pg} \mathrm{m}^{-3} \mathrm{yr}^{-1}$ ). A recent study covering both stations over the same period (2000-2009) showed some similarities and some differences (Cole et al., 2013). From January to August the GEM levels from the two stations showed similar trends. January-March and July showed decreasing trends for both the stations, but the trends were in general stronger for Alert. April and May showed increasing trends for both stations, but April was higher for Alert. The increasing trend seen at Zeppelin in April and May could be due to less frequent AMDEs and higher GEM concentrations and is discussed in the next sections. September to December showed, in general, positive trends for Zeppelin and negative trends for Alert. Hirdmann et al. (2009) showed that the fall results were the most difficult to explain for Zeppelin. They seemed to indicate quite a strong influence (sources) for air masses transported from the North Atlantic. Cole et al. conclude that the increasing trend seen at Zeppelin in fall could be due to re-emission from the Arctic Ocean, where the sea ice is at a minimum during this time of year and has been decreasing. This is discussed in detail in Cole et al. (2013).

\subsection{AMDEs: seasonal and annual variations}

Episodic depletions of GEM concentrations at Zeppelin station are seen during the months following polar sunrise (starting 19 February at this latitude) and have been discussed in the literature (Berg et al., 2003; Aspmo et al., 2005; Steen et al., 2011). AMDEs start at least one month after polar sunrise (late March) and the concentration of GEM can drop from $1.8 \mathrm{ng} \mathrm{m}^{-3}$ to well below $0.1 \mathrm{ng} \mathrm{m}^{-3}$ (Aspmo et al., 2005). Figure 5a shows the monthly percent distribution of AMDEs from 2000 to 2009. AMDEs are evenly distributed between April and May as 44 and $42 \%$, respectively (Fig. 5a), and

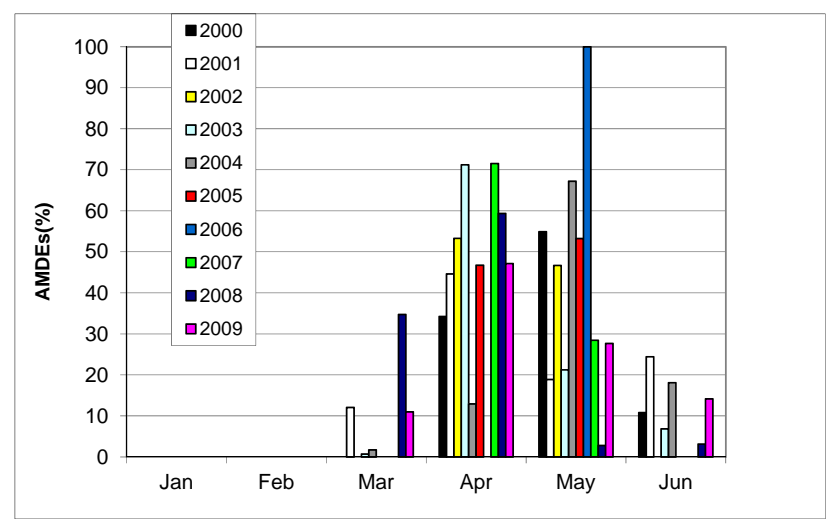

Fig. 5a. Monthly distribution (\%) of AMDEs at Zeppelin.

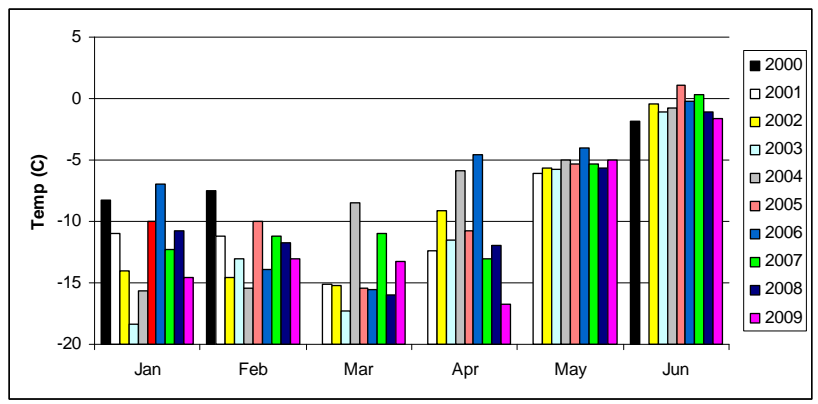

Fig. 5b. Monthly temperature averages (January-June) at Zeppelin for 2000-2009.

fewer in March and June (6 and $8 \%$ of the time, respectively). We report no change in the timing frequency of depletion events. For example, 2001, 2003 and 2007 were years when April was the predominant month for AMDEs and in 2000, 2004 and 2006 most AMDEs occurred in May. In 2002 and 2005 there was an equal distribution of AMDEs between the two months and none have been reported earlier than March. The frequency of AMDEs was investigated in relation to ambient air temperature at the site. When AMDEs were predominately in April, the average temperatures for April and May were -12.3 and $-5.7^{\circ} \mathrm{C}$, respectively (Fig. 5b). The average temperatures for the years when AMDEs were equally distributed between the two months were -10 for April and $-5.5^{\circ} \mathrm{C}$ for May. For the years when AMDEs mostly occurred in May the average temperatures were -5.2 in April and $-4.5^{\circ} \mathrm{C}$ in May, thus lower average temperatures may relate to AMDE's timing and is discussed in detail in Sect. 3.3.

The average sea ice extent for the Arctic Ocean was investigated for its relationship with the frequency of AMDEs from March to June and is shown in Fig. 6. The highest frequency of AMDEs is reported in 2000 and the lowest in 2006. From 2007 to 2009, there is an increase in the percent of hours of AMDEs. Recent changes in the sea ice cover in the Arctic Ocean can affect the cycling of mercury in polar 
Table 1. Correlations of median monthly GEM with climate indices, and regional sea ice. Coefficients in bold are significant at the $p<0.05$ level. AO, Arctic Oscillation; NAO, North Atlantic Oscillation; EA, East Atlantic pattern; PNA, Pacific/North American pattern; EA/WR, East Atlantic/West Russia pattern; SCA, Scandinavia pattern; POL, Polar/Eurasia pattern. Sea ice regions are defined by NSIDC and shown in Fig. 1.

\begin{tabular}{lrrrrrrrrrrr}
\hline & AO & NAO & EA & PNA & EA/WR & SCA & POL & $\begin{array}{r}\text { Northern } \\
\text { Hemisphere ice }\end{array}$ & $\begin{array}{r}\text { Greenland } \\
\text { Sea ice }\end{array}$ & $\begin{array}{r}\text { Kara and Barents } \\
\text { seas ice }\end{array}$ & $\begin{array}{r}\text { Arctic } \\
\text { Ocean ice }\end{array}$ \\
\hline Jan & -0.50 & -0.70 & 0.72 & $\mathbf{0 . 9 3}$ & -0.44 & 0.63 & 0.32 & 0.77 & 0.79 & 0.33 \\
Feb & 0.48 & 0.62 & 0.31 & 0.39 & 0.22 & -0.34 & -0.38 & 0.31 & -0.10 & 0.23 \\
Mar & 0.57 & 0.65 & -0.25 & 0.01 & 0.33 & 0.64 & 0.10 & -0.61 & $-\mathbf{0 . 7 8}$ & 0.15 & -0.47 \\
Apr & -0.36 & 0.11 & 0.29 & 0.47 & -0.14 & 0.34 & -0.08 & -0.32 & -0.57 & -0.32 \\
May & 0.47 & 0.35 & 0.51 & 0.12 & 0.25 & 0.02 & 0.35 & -0.10 & 0.09 & 0.38 & -0.08 \\
Jun & -0.08 & 0.07 & -0.07 & 0.49 & 0.14 & 0.40 & $\mathbf{0 . 8 2}$ & -0.17 & -0.22 & 0.10 & -0.39 \\
Jul & 0.52 & 0.10 & $\mathbf{0 . 7 4}$ & 0.34 & 0.29 & 0.21 & 0.41 & -0.11 & -0.37 & 0.12 & -0.25 \\
Aug & -0.11 & -0.05 & 0.07 & 0.04 & -0.45 & 0.21 & -0.08 & -0.45 & -0.16 & 0.17 & -0.04 \\
Sep & -0.66 & -0.12 & -0.06 & 0.29 & -0.09 & 0.31 & 0.24 & $-\mathbf{0 . 7 6}$ & 0.51 & -0.05 & -0.43 \\
Oct & 0.38 & 0.38 & -0.11 & 0.32 & -0.22 & -0.13 & 0.07 & -0.58 & 0.45 & -0.12 & $-\mathbf{0 . 7 5}$ \\
Nov & -0.41 & -0.06 & 0.10 & 0.19 & -0.10 & -0.02 & -0.51 & -0.53 & 0.29 & -0.27 & -0.55 \\
Dec & -0.19 & -0.41 & 0.66 & 0.04 & -0.00 & 0.32 & -0.34 & -0.30 & 0.20 & -0.35 & -0.48 \\
\hline
\end{tabular}

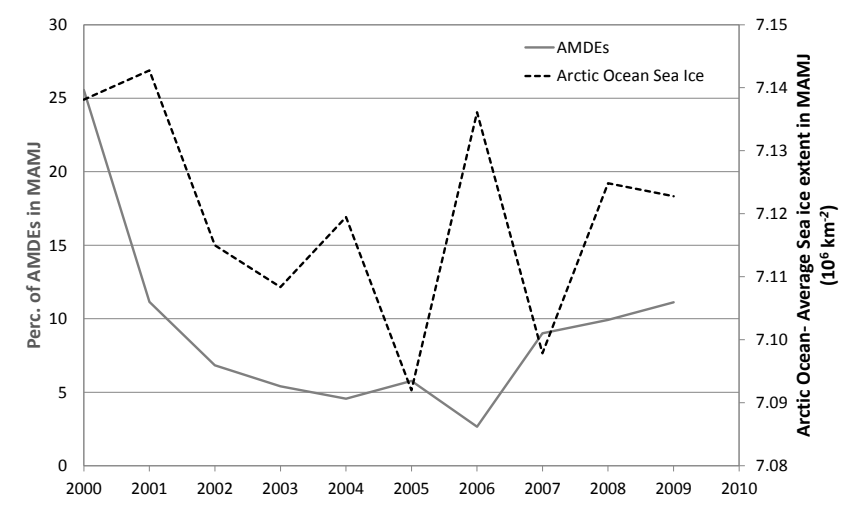

Fig. 6. Percent of AMDE hours in March, April, May and June relative to the total measurements for the same period for the period 2000-2009 (solid line). Average sea ice extent over the Arctic Ocean for the same months and years $\left(\mathrm{km}^{-2}\right)$ (dashed line).

regions (Andersson et al., 2008), but no significant correlation was seen between the frequency of AMDEs at Zeppelin and the sea ice extent for the Arctic Ocean for this fourmonth period (Table 1). Ny-Ålesund is located at Kongsfjorden and while this ice is likely not an important source for AMDEs at Zeppelin, it can be used as an example of localscale changes in the sea. In general, the fjord has been ice covered in the past but from 2006 to 2008 no permanent ice was seen on Kongsfjorden. Cottier et al. (2007) showed that, during the winter of 2005/2006, periods of sustained alongshelf winds generated upwelling and cross-shelf exchange causing extensive flooding of the coastal waters with warm Atlantic water from the West Spitsbergen Current. The winter temperature of the West Spitsbergen Shelf reverted to that of typical fall and interrupted the normal cycle of sea ice formation in the region (Cottier et al., 2007). The warm sea wa- ter from 2005/2006 was not fully replaced with cold water in $2006 / 2007$ and 2007/2008, preventing sea ice formation on the local fjords during these winters. By studying the ice extent for the Arctic Ocean, large changes can be seen (Fig. 6). The halide species necessary for the AMDEs are presumably derived from the sea ice (Steffen et al., 2008).

\subsection{Correlation of AMDEs with meteorological and climate parameters}

GEM concentrations were calculated as a function of various meteorological parameters including temperature, wind direction, wind speed, relative humidity and time of day. The data were first divided by month for each parameter and then the GEM values were plotted as a function of each parameter. The results are shown in Fig. 7a-e as box and whisker plots. The data were divided into bins and each vertical line indicates their dividing line (e.g. temperature is binned into 5 degree increments, such as -25 to $-20^{\circ} \mathrm{C},-20$ to $-15^{\circ} \mathrm{C}$, etc.).

The first parameter investigated was air temperature between -30 and $+10^{\circ} \mathrm{C}$. GEM concentrations were found to decrease with decreasing temperature for all the months (Fig. 7a). There were few low GEM levels reported in March, which is expected given the timing of AMDEs, as discussed above. Lower concentrations of GEM were seen in May than in April for most of the temperatures below $0^{\circ} \mathrm{C}$. In June, low GEM values occurred only when the temperature was between -5 and $-10^{\circ} \mathrm{C}$, which were the lowest temperatures recorded for that month. This relationship between GEM concentration and low air temperature supports earlier studies on the temperature dependence of AMDEs that are likely due to temperature effects in the formation of brine, the chemistry of bromine, and the reactivity of bromine radicals with GEM (Steffen et al., 2008). The freezing of sea 


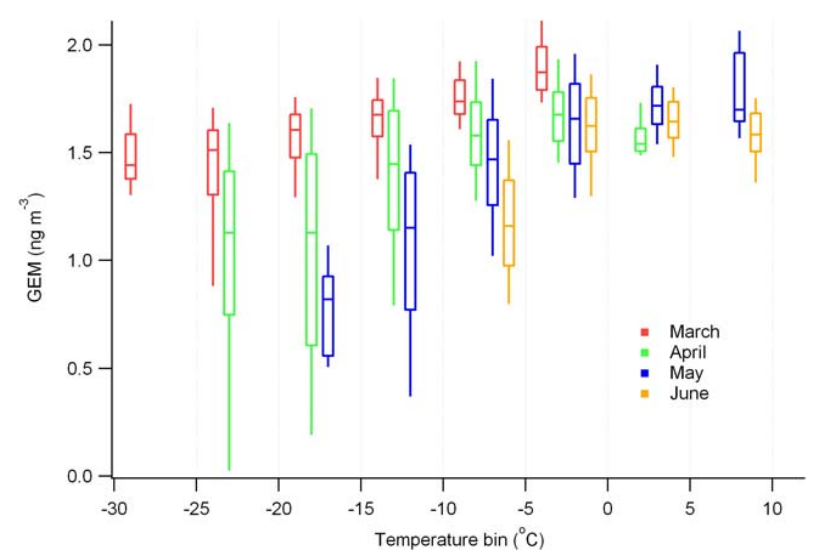

Fig. 7a. Box-and-whisker plots showing the median (horizontal line), 25th and 75th percentiles (box), and 10th and 90th percentiles (whiskers) for the distribution of GEM values in each temperature bin during each of the four AMDE months. A minimum of 20 points was required in each bin.

water, which causes brine to be pushed to the surface of the newly forming sea ice, is caused by cold temperatures (less than $-13^{\circ} \mathrm{C}$ ) and is likely involved in providing a saline surface on which halogen activation can occur (Simpson et al., 2007). Adams et al. (2002) showed that the conversion of bromide ions (in aerosol or snow to $\mathrm{Br}_{2}$ ) may be enhanced at lower temperatures. This may either be due to the increasing concentration of halides in the reactive liquid layer of the snow pack (Koop et al., 2000) or acidification of sea salt aerosol (Sander et al., 2006). Theoretical calculations of the reaction rate in the reactions that oxidize GEM to GOM have predicted an inverse temperature dependence at the low temperatures (less than $-13^{\circ} \mathrm{C}$ ) seen in the Arctic during spring (Goodsite et al., 2004). A large fraction of the AMDEs reported at $\mathrm{Ny}$-Ålesund are suspected to result from the long-range transport of air masses containing depleted GEM from areas over the Arctic Ocean with low temperatures from where the chemistry could have been initiated (Gauchard et al., 2005; Steen et al., 2011). Although the local temperature is not always sufficiently low to initiate the depletion chemistry, the temperatures may have been low enough at the origin of the advected air masses (Berg et al., 2008b). The highest GEM concentration levels reported at the Zeppelin site were seen on the warmest days in March $(0$ to $-5^{\circ} \mathrm{C}$ ) (Fig. 7a). This was likely re-emission of previously deposited mercury as earlier shown by Steen et al. (2009), where from February to mid-June 2008 GEM fluxes above a snow covered surface were measured in Ny-Ålesund using a GEM flux gradient method. In that study, the GEM emission from the surface snow to the air was most pronounced from 24 March until 12 May suggesting that deposition of GOM and PBM during AMDEs is the main precursor for the emitted GEM.

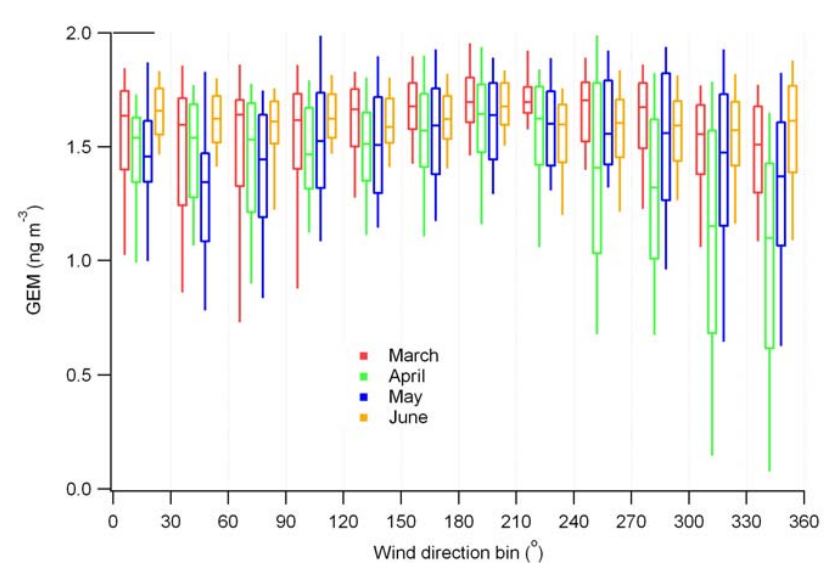

Fig. 7b. Box-and-whisker plots showing the median (horizontal line), 25th and 75th percentiles (box), and 10th and 90th percentiles (whiskers) for the distribution of GEM values in each wind direction bin during each of the four AMDE months. A minimum of 20 points was required in each bin.

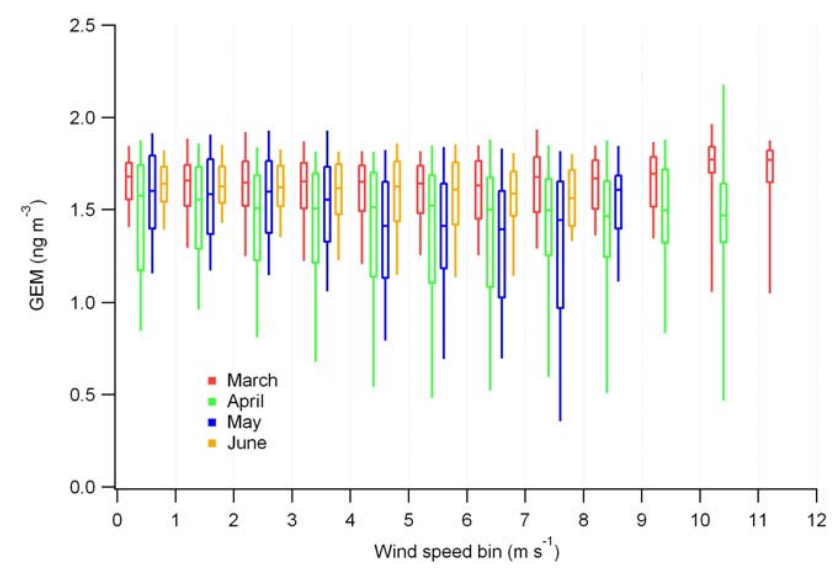

Fig. 7c. Box-and-whisker plots showing the median (horizontal line), 25th and 75th percentiles (box), and 10th and 90th percentiles (whiskers) for the distribution of GEM values in each wind speed bin during each of the four AMDE months. A minimum of 20 points was required in each bin.

GEM concentration levels and wind direction were also plotted, in 30 degree bins, to assess if any correlations exist (Fig. 7b). The lowest GEM values in the data set $\left(<0.5 \mathrm{ng} \mathrm{m}^{3}\right)$ were seen in April when the wind was blowing from north/north-west $\left(300\right.$ to $\left.360^{\circ}\right)$. Air masses from this direction arrive from the Canadian Arctic or Arctic Ocean. Slightly higher GEM concentrations $\left(0.5-1.0 \mathrm{ng} \mathrm{m}^{-3}\right)$ were recorded when there were westerly winds $\left(240-300^{\circ}\right.$ from Greenland) in April. Similarly in May, the same pattern was found with lower concentrations. North-easterly winds (30-90 $0^{\circ}$ from Siberia) in March, April and May result in GEM concentrations just below $1.0 \mathrm{ng} \mathrm{m}^{-3}$; and in June the lowest GEM levels were from the north $\left(360^{\circ}-\right.$ central 


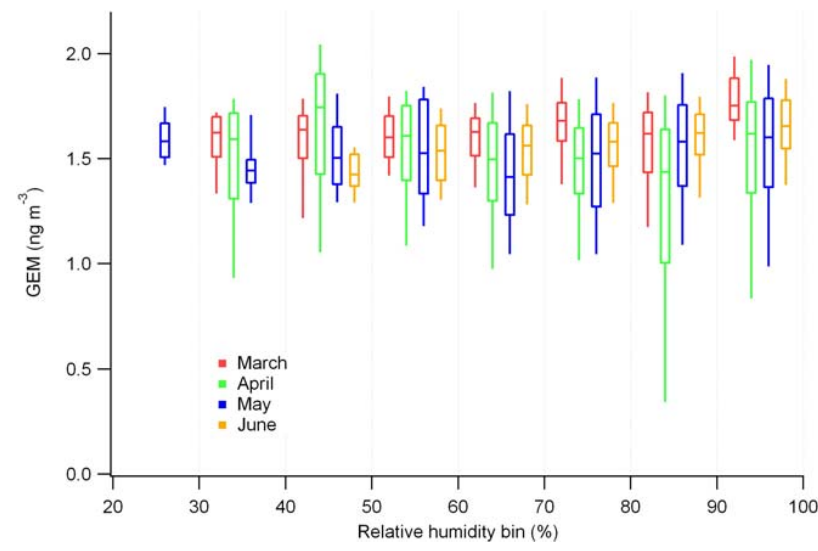

Fig. 7d. Box-and-whisker plots showing the median (horizontal line), 25th and 75th percentiles (box), and 10th and 90th percentiles (whiskers) for the distribution of GEM values in each relative humidity bin during each of the four AMDE months. A minimum of 20 points was required in each bin.

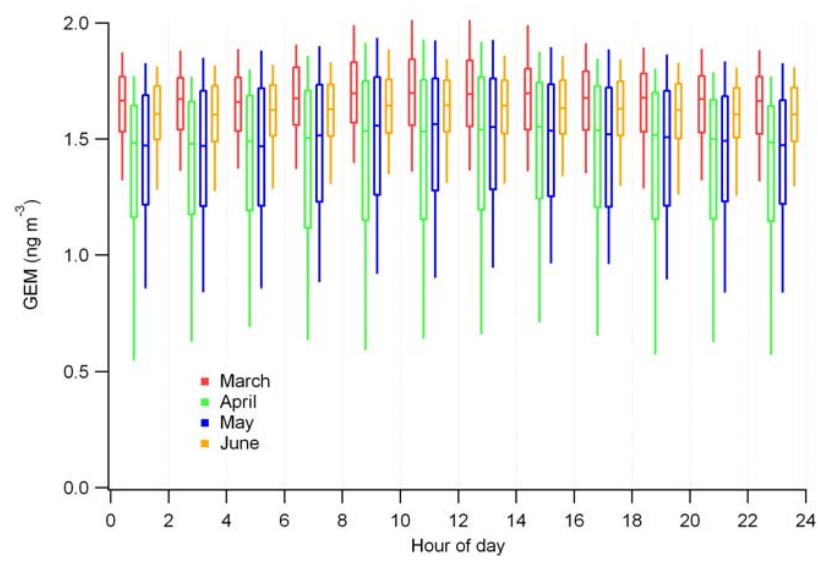

Fig. 7e. Box-and-whisker plots showing the median (horizontal line), 25th and 75th percentiles (box), and 10th and 90th percentiles (whiskers) for the distribution of GEM values in each hour of day bin during each of the four AMDE months. A minimum of 20 points was required in each bin.

Arctic). During the AMDE period, the highest GEM concentrations (median: $1.68 \mathrm{ng} \mathrm{m}^{-3}$ ) were reported in March when the winds came from south at $180^{\circ}$ (Fig. $7 \mathrm{~b}$ ) and, in April and May, the highest concentrations were also seen with southerly winds. The source and sink regions for the data between 2000 and 2008 were examined using a Lagrangian particle dispersion model (Hirdman et al., 2009). That study found that low GEM concentrations in AprilMay were strongly associated with low-level transport of air masses across a sea ice covered Arctic Ocean (300 to $360^{\circ}$ /north-northwest), providing evidence for the influence of AMDEs at Zeppelin station. Using a trajectory climatology model, Eneroth et al. (2007) found that the lowest concentrations of GEM at Zeppelin (2000-2001) arrived from
Siberia $\left(60^{\circ}\right.$ - north-east), the Barents Sea $\left(90^{\circ}\right.$ - east $)$ and the Norwegian Sea $\left(210^{\circ}\right.$ - south-west) in April-May, and from the Canadian Arctic $\left(270^{\circ}\right.$ - north-west) and the Arctic Ocean $\left(90^{\circ}-\right.$ north) area in May-June. It was suggested the one month lag between the two source regions could either be due to the position of the marginal ice zone or the temperature differences between the north-western and north-eastern air masses.

Wind speeds were also investigated to see how this may affect GEM concentration levels (Fig. 7c). While there was no linear correlation between GEM and wind speed $\left(R^{2}<0.050\right)$, the lowest GEM values correlate with wind speeds between 4 and $11 \mathrm{~m} \mathrm{~s}^{-1}$ in April and May. Low wind speeds are commonly reported during AMDEs and can be the result of a stable marine boundary layer (Steffen et al., 2008), but that is not the case in this study. At Zeppelin, the highest GEM concentrations were seen in March when the winds were between 10 and $12 \mathrm{~m} \mathrm{~s}^{-1}$ (Fig. 7c). The correlation of AMDEs with wind speed was also reported to be weaker than with temperature at both Alert and Amderma (Cole and Steffen, 2010).

Relative humidity did not correlate with GEM concentrations (Fig. 7d). In April, the lowest GEM values were when the relative humidity was between 80 and $90 \%$, which is just above the April average for the station, and the highest GEM concentrations were in the relative humidity range 40-50\% (Fig. 7d). However, these are not consistent between months and likely not meaningful. Absolute water content was also compared to GEM concentrations but, since the value for water content is so dependent on temperature, the resulting box plot was nearly identical to Fig. 7a.

Very small diurnal variability was observed in the GEM concentrations (Fig. 7e). This is in contrast to GEM measurements at NILU's Troll station in Antarctica where no diurnal pattern was observed (Pfaffhuber et al., 2012). The main difference between the two stations is that Troll is located on snow free bedrock whereas the area surrounding Zeppelin is snow covered for a large part of the year. The diurnal pattern at Zeppelin is likely caused by daytime snow surface emissions induced by solar radiation where the solar maximum is in hour 12.

The role of UV radiation was explored by linear correlations between GEM and UVB dose rates rather than binned box plots because the range of UVB values in March was much smaller than in June. Monthly median GEM values for each month were plotted against the simulated UVB dose rate for that month from 2000 to 2009 where each point represents a given year. These plots and linear regression fits for March and April are shown in Figure 8. The March correlation shows that there is a positive significant correlation between the average UVB dose rate and the monthly median GEM levels $\left(R^{2}=0.93, p<0.001\right)$. This relationship may be tied to increased snow surface emissions since the higher levels $\left(>1.8 \mathrm{ng} \mathrm{m}^{-3}\right)$ are above hemispheric background (1.5$\left.1.7 \mathrm{ng} \mathrm{m}^{-3}\right)$. In April, median GEM concentrations were 


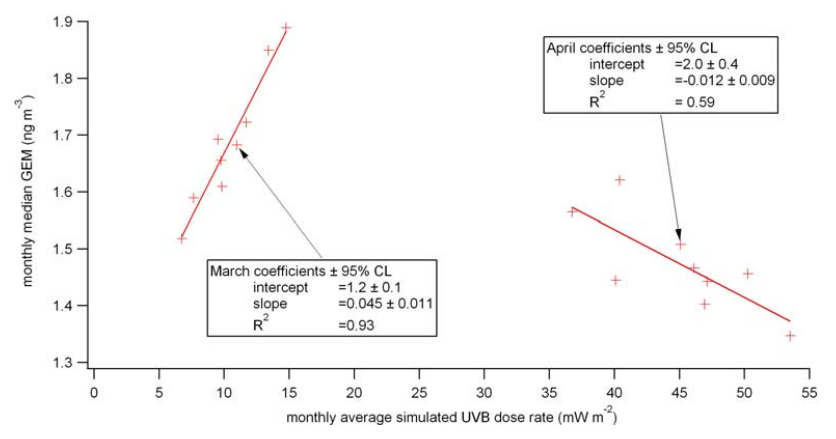

Fig. 8. Monthly median GEM vs. average monthly UVB dose rate at Zeppelin for $10 \mathrm{yr}$ of data, March and April data only, with leastsquares regression lines.

inversely correlated with the average UVB dose rate on an interannual basis $\left(R^{2}=0.59, p=0.016\right)$. In this plot the years where the UVB dose rates are high include low median GEM, which suggests that the oxidation of GEM is photoinitiated. No significant correlations were found in May or June (not shown). The competition between these two effects on the GEM levels (surface emission and atmospheric oxidation) may explain the poor correlations on a finer timescale.

In addition to the local meteorological parameters, largescale transport patterns and the quantity of sea ice may affect the GEM levels measured at Zeppelin. Altered atmospheric fields imply the possibility that the transport of $\mathrm{Hg}$ into and out of the Arctic can be altered (AMAP, 2011). The North Atlantic Oscillation index (NOA) is the most important index for climate variability in the Northern Hemisphere. For example, during the past decade, the Arctic's atmospheric pressure pattern has been characterized by anomalously high sea-level pressure on the North American side of the Arctic and low pressure on the Eurasian side (Overland et al., 2008), which has then supported more southerly winds. The correlations of monthly median GEM concentrations with several Northern Hemisphere climate indices were calculated for every month and the resulting correlation coefficients are listed in Table 1. This analysis was done to assess if these climate parameters reflect different atmospheric conditions that can enhance or reduce spring AMDE activity from year to year. This was also done to assess whether enhanced transport during the non-AMDE seasons is associated with higher GEM concentrations. From Table 1 it is clear that there are no consistent patterns where GEM concentrations correlate with these indices. A few cases show statistically significant relationships between the parameters and climate indices $(p<0.05)$ for a single month. However, this may be an artefact of the number of relationships examined; given a single data set with a large number of variables, some will randomly have significant statistical relationships with each other. We conclude that there was correlation between the NAO and GEM at Zeppelin. In contrast, at
Alert a significant negative correlation was reported between AMDEs and both the NAO and the Polar/Eurasia teleconnection, indicating that AMDEs were more intense when the circumpolar vortex was strong (Cole and Steffen, 2010). In March, at Zeppelin there was a negative relationship between the Greenland Sea ice and GEM. The years where more sea ice in the Greenland Sea was reported showed more AMDEs and lower GEM at Zeppelin. While the results may suggest a similar pattern with the sea ice levels in the Kara and Barents seas, the Arctic Sea, and the whole Northern Hemisphere, the correlations were not significant $(p>0.05)$. In September, negative relationships between GEM and both the Northern Hemispheric ice and Arctic Ocean ice were found. The years with more sea ice in these areas were found to correlate with the lowest GEM concentrations and could be a result of less GEM evasion from the ocean to the atmosphere. There was no significant correlation between the Greenland Sea ice and GEM in September and is likely due to little to no Greenland Sea ice present at that time.

\section{Conclusions}

Gaseous elemental mercury measurements (GEM) at the Zeppelin station in Ny Ålesund have shown no annual increasing or decreasing trend for the period from 2000 to 2009. This result is in agreement with earlier studies made from the same station, but is in contrast to observations made at Alert, Canada (also in the High Arctic), and Mace Head, Ireland (temperate, coastal region), where significant annual decreases in GEM concentrations have been reported over the same time period. The differences observed in the trends between the three stations may reflect changes in the anthropogenic emissions of GEM. Total global anthropogenic emissions of GEM have reported small increases during this period although there have been significant changes in amount from given source regions. Emissions from Europe and North America have decreased while those from China have increased. The lack of an annual trend at Zeppelin could reflect changes in the transport and/or circulation patterns that influence the air masses that reach this area of the Arctic. However, there were no strong correlations with major climate indices such as NAO or AO with the GEM concentration data from Zeppelin, therefore we conclude that this is not the likely reason for the lack of a trend. Increased re-emission of GEM from an Arctic Ocean caused by decreasing sea ice cover (due to climate warming) is another explanation for the lack of annual trends at the Zeppelin station during this time period. The Zeppelin GEM data showed decreasing trends in some months (January, February, March and June) but the remainder of the year reflect increasing trends.

AMDEs are equally reported in April and May at the Zeppelin station. The percentage of AMDEs in March, April, May and June compared to the total number of measurements 
have varied over the years with no discernible long-term trend.

Several meteorological factors (such as temperature, wind direction, wind speed and relative humidity) were investigated to assess any significant relationships with GEM concentrations. Lower concentrations of GEM were seen at lower temperatures below a threshold of $0^{\circ}$. The lowest GEM values were observed when wind speeds were between 4 and $11 \mathrm{~m} \mathrm{~s}^{-1}$ in April and May. This is probably from advected air masses containing depleted $\mathrm{Hg}$. Slight diurnal variations in the GEM concentrations were observed, likely caused by daytime snow surface emissions that can be induced by solar radiation and increases in temperature. The relationship between UVB and GEM in March was found to be positively correlated and negatively correlated in April. This implies that two different UV driven processes occur in March and April. Investigation of several climate indices with GEM levels showed no discernible correlations but total sea ice extent was found, at times, to relate to GEM levels.

The results in this study have shown that GEM at Zeppelin, Svalbard, behaves differently from other stations in the high Arctic and in Europe both on short and long timescales. Ten years of GEM data may be too few to reveal meaningful correlations with climate indices and sea ice extent due to the high amount of interannual variability. Continued monitoring of GEM is therefore highly recommended both at Zeppelin and other locations. Long-term time series of GEM and other atmospheric mercury species are also important to better understand the processes involved in the cycling of $\mathrm{Hg}$ in the polar atmosphere and to see possible effects on AMDEs and long-term deposition of $\mathrm{Hg}$ to the polar regions from changes in global anthropogenic $\mathrm{Hg}$ emissions.

Acknowledgements. The authors wish to thank The Norwegian Climate and Pollution Directorate and the Norwegian Research Council (MILJØ 2015) for funding. We are grateful for the technical support offered by the NPI staff at the Sverdrup station. We also want to thank our excellent technicians and instrument care takers Jan H. Wasseng and Are Bäcklund.

Edited by: A. Dastoor

\section{References}

Adams, J. W., Holmes, N. S., and Crowley, J. N.: Uptake and reaction of $\mathrm{HOBr}$ on frozen and dry $\mathrm{NaCl} / \mathrm{NaBr}$ surfaces between 253 and 233 K, Atmos. Chem. Phys., 2, 79-91, doi:10.5194/acp2-79-2002, 2002.

AMAP: AMAP Assessment 2011: Mercury in the Arctic. , Arctic Monitoring and Assessment Programme (AMAP), Oslo, Norway, xiv + 193 pp., 2011.

AMAP/UNEP: Technical Background Report for the Global Mercury Assessment 2013 Arctic Monitoring and Assessment Programme (AMAP), Oslo, Norway/UNEP Chemicals Branch, Geneva, Switzerland VI‘+263 pp., 2013.
Andersson, M. E., Sommar, J., Gardfeldt, K., and Lindqvist, O.: Enhanced concentrations of dissolved gaseous mercury in the surface waters of the Arctic Ocean, Mar. Chem., 110, 190-194, doi:10.1016/j.marchem.2008.04.002, 2008.

Aspmo, K., Gauchard, P.-A., Steffen, A., Temme, C., Berg, T., Bahlmann, E., Banic, C., Dommergue, A., Ebinghaus, R., Ferrari, C., Pirrone, N., Sprovieri, F., and Wibetoe, G.: Measurements of atmospheric mercury species during an international study of mercury depletion events at Ny-Alesund, Svalbard, spring 2003. How reproducible are our present methods?, Atmos. Environ., 39, 7607-7619, 2005.

Aspmo, K., Temme, C., Berg, T., Ferrari, C., Gauchard, P. A., Fain, X., and Wibetoe, G.: Mercury in the atmosphere, snow and melt water ponds in the North Atlantic Ocean during Arctic summer, Environ. Sci. Technol., 40, 4083-4089, 2006.

Berg, T., Sekkesaeter, S., Steinnes, E., Valdal, A.-K., and Wibetoe, G.: Springtime depletion of mercury in the European Arctic as observed at Svalbard, Sci. Total Environ., 304, 43-51, 2003.

Berg, T., Kallenborn, R., and Mano, S.: Temporal trends in atmospheric heavy metal and organochlorine concentrations at Zeppelin, Svalbard, Arctic Antarctic and Alpine Research, 36, 284291, 2004.

Berg, T., Aas, W., Pacyna, J., Uggerud, H. T., and Vadset, M.: Atmospheric trace metal concentrations at Norwegian background sites during 25 years and its relation to European emissions, Atmos. Environ., 42, 7494-7501, doi:10.1016/j.atmosenv.2008.05.020, 2008a.

Berg, T., Aspmo, K., and Steinnes, E.: Transport of Hg from Atmospheric mercury depletion events to the mainland of Norway and its possible influence on $\mathrm{Hg}$ deposition, Geophys. Res. Lett., 35, L09802, doi:10.1029/2008g1033586, 2008b.

Cobbett, F. D., Steffen, A., Lawson, G., and Van Heyst, B. J.: GEM fluxes and atmospheric mercury concentrations (GEM, RGM and Hg-P) in the Canadian Arctic at Alert, Nunavut, Canada (February-June 2005), Atmos. Environ., 41, 6527-6543, doi:10.1016/j.atmonsenv.2007.04.033, 2007.

Cole, A. S. and Steffen, A.: Trends in long-term gaseous mercury observations in the Arctic and effects of temperature and other atmospheric conditions, Atmos. Chem. Phys., 10, 4661-4672, doi:10.5194/acp-10-4661-2010, 2010.

Cole, A. S., Steffen, A., Pfaffhuber, K. A., Berg, T., Pilote, M., Poissant, L., Tordon, R., and Hung, H.: Ten-year trends of atmospheric mercury in the high Arctic compared to Canadian subArctic and mid-latitude sites, Atmos. Chem. Phys., 13, 15351545, doi:10.5194/acp-13-1535-2013, 2013.

Corbitt, E. S., Jacob, D. J., Holmes, C. D., Streets, D. G., and Sunderland, E. M.: Global Source-Receptor Relationships for Mercury Deposition Under Present-Day and 2050 Emissions Scenarios, Environ. Sci. Technol., 45, 10477-10484, doi:10.1021/es202496y, 2011.

Cottier, F. R., Nilsen, F., Inall, M. E., Gerland, S., Tverberg, V., and Svendsen, H.: Wintertime warming of an Arctic shelf in response to large-scale atmospheric circulation, Geophys. Res. Lett., 34, L10607 doi:10.1029/2007g1029948, 2007.

Ebinghaus, R., Kock, H. H., Temme, C., Einax, J. W., Lowe, A. G., Richter, A., Burrows, J. P., and Schroeder, W. H.: Antarctic springtime depletion of atmospheric mercury, Environ. Sci. Technol., 36, 1238-1244, doi:10.1021/es015710z, 2002. 
Ebinghaus, R., Jennings, S. G., Kock, H. H., Derwent, R. G., Manning, A. J., and Spain, T. G.: Decreasing trends in total gaseous mercury observations in baseline air at Mace Head, Ireland from 1996 to 2009, Atmos. Environ., 45, 3475-3480, doi:10.1016/j.atmosenv.2011.01.033, 2011.

Eneroth, K., Holmén, K., Berg, T., Schmidbauer, N., and Solberg, S.: Springtime depletion of tropospheric ozone, gaseous elemental mercury and non-methane hydrocarbons in the European Arctic, and its relation to atmpospheric transport, Atmos. Environ., 41, 8511-8526, 2007.

Fetterer, F., Knowles, K., Meier, W., and Savoie, M.: Sea Ice Index, National Snow and Ice Data Center, Boulder CO, available at: http://nsidc.org/data/seaice_index, 2002, updated 2012.

Gauchard, P.-A., Aspmo, K., Temme, C., Steffen, A., Ferrari, C., Berg, T., Strom, J., Kaleschke, L., Dommergue, A., Bahlmann, E., Magand, O., Planchon, F., Ebinghaus, R., Banic, C., Nagorski, S., Baussand, P., and Boutron, C.: Study of the origin of atmospheric mercury depletion events recorded in $\mathrm{Ny}$ Alesund, Svalbard, spring 2003, Atmos. Environ., 39, 76207632, 2005.

Gilbert, R. O.: Statistical methods for environmental pollution monitoring, in, Van Nostrand Reinhold, New York, 1987.

Goodsite, M. E., Plane, J. M. C., and Skov, H.: A theoretical study of the oxidation of $\mathrm{Hg}-0$ to $\mathrm{HgBr} 2$ in the troposphere, Environ. Sci. Technol., 38, 1772-1776, doi:10.1021/es034680s, 2004.

Hedgecock, I. M. and Pirrone, N.: Chasing quicksilver: Modeling the atmospheric lifetime of $\mathrm{Hg}-(\mathrm{g})(0)$ in the marine boundary layer at various latitudes, Environ. Sci. Technol., 38, 69-76, doi:10.1021/es034623z, 2004.

Hirdman, D., Aspmo, K., Burkhart, J. F., Eckhardt, S., Sodemann, H., and Stohl, A.: Transport of mercury in the Arctic atmosphere: Evidence for a spring-time net sink and summer-time source, Geophys. Res. Lett., 36, L12814, doi:10.1029/2009g1038345, 2009.

Kahl, J. D. W., Galbraith, J. A., and Martinez, D. A.: Decadal-scale variability in long-range atmospheric transport to the Summit of the Greenland Ice Sheet, Geophys. Res. Lett., 26, 481-484, doi:10.1029/1999g1900021, 1999.

Koop, T., Kapilashrami, A., Molina, L. T., and Molina, M. J.: Phase transitions of sea-salt/water mixtures at low temperatures: Implications for ozone chemistry in the polar marine boundary layer, J. Geophys. Res.-Atmos., 105, 26393-26402, doi:10.1029/2000jd900413, 2000.

Lindberg, S. E., Brooks, S., Lin, C. J., Scott, K. J., Landis, M. S., Stevens, R. K., Goodsite, M., and Richter, A.: Dynamic oxidation of gaseous mercury in the Arctic troposphere at polar sunrise, Environ. Sci. Technol., 36, 1245-1256, 2002.

Mayer, B. and Kylling, A.: Technical note: The libRadtran software package for radiative transfer calculations - description and examples of use, Atmos. Chem. Phys., 5, 1855-1877, doi:10.5194/acp-5-1855-2005, 2005.

Molina, L. T., and Molina, M. J.: Absolute absorption crosssections of ozone in the 185-NM TO 350-NM wavelength range, J. Geophys. Res.-Atmos., 91, 14501-14508, doi:10.1029/JD091iD13p14501, 1986.

Overland, J. E., Wang, M., and Salo, S.: The recent Arctic warm period, Tellus A, 60, 589-597, doi:10.1111/j.16000870.2008.00327.x, 2008.
Pacyna, E. G., Pacyna, J. M., Sundseth, K., Munthe, J., Kindbom, K., Wilson, S., Steenhuisen, F., and Maxson, P.: Global emission of mercury to the atmosphere from anthropogenic sources in 2005 and projections to 2020, Atmos. Environ., 44, 2487-2499, 2010.

Pacyna, J. M., Pacyna, E. G., and Aas, W.: Changes of emissions and atmospheric deposition of mercury, lead, and cadmium, Atmos. Environ., 43, 117-127, doi:10.1016/j.atmosenv.2008.09.066, 2009.

Pfaffhuber, K. A., Berg, T., Hirdman, D., and Stohl, A.: Atmospheric mercury observations from Antarctica: seasonal variation and source and sink region calculations, Atmos. Chem. Phys., 12, 3241-3251, doi:10.5194/acp-12-3241-2012, 2012.

Poissant, L.: Time series analysis of atmospheric mercury in $\mathrm{Ku}-$ ujjuarapik/Whapmagoostui (Quebec), Journal de Physique, 107, 1079-1082, 2003

Sander, R., Burrows, J., and Kaleschke, L.: Carbonate precipitation in brine - a potential trigger for tropospheric ozone depletion events, Atmos. Chem. Phys., 6, 4653-4658, doi:10.5194/acp-64653-2006, 2006.

Schroeder, W. H. and Munthe, J.: Atmospheric mercury - An overview, Atmos. Environ., 32, 809-822, doi:10.1016/s13522310(97)00293-8, 1998.

Schroeder, W. H., Anlauf, K. G., Barrie, L. A., Lu, J. Y., Steffen, A., Schneeberger, D. R., and Berg, T.: Arctic springtime depletion of mercury, Nature, 394, 331-332, 1998.

Selin, N. E., Jacob, D. J., Park, R. J., Yantosca, R. M., Strode, S., Jaegle, L., and Jaffe, D.: Chemical cycling and deposition of atmospheric mercury: Global constraints from observations, J. Geophys. Res.-Atmos., 112, D02308, doi:10.1029/2006jd007450, 2007.

Simpson, W. R., von Glasow, R., Riedel, K., Anderson, P., Ariya, P., Bottenheim, J., Burrows, J., Carpenter, L. J., Frieß, U., Goodsite, M. E., Heard, D., Hutterli, M., Jacobi, H.-W., Kaleschke, L., Neff, B., Plane, J., Platt, U., Richter, A., Roscoe, H., Sander, R., Shepson, P., Sodeau, J., Steffen, A., Wagner, T., and Wolff, E.: Halogens and their role in polar boundary-layer ozone depletion, Atmos. Chem. Phys., 7, 4375-4418, doi:10.5194/acp-74375-2007, 2007.

Skov, H., Christensen, J. H., Goodsite, M. E., Heidam, N. Z., Jensen, B., Wahlin, P., and Geernaert, G.: Fate of elemental mercury in the arctic during atmospheric mercury depletion episodes and the load of atmospheric mercury to the arctic, Environ. Sci. Technol., 38, 2373-2382, 2004.

Slemr, F., Brunke, E. G., Ebinghaus, R., Temme, C., Munthe, J., Wangberg, I., Schroeder, W., Steffen, A., and Berg, T.: Worldwide trend of atmospheric mercury since 1977, Geophys. Res. Lett., 30, doi:10.1029/2003GL016954, 2003.

Steen, A. O., Berg, T., Dastoor, A. P., Durnford, D. A., Hole, L. R., and Pfaffhuber, K. A.: Dynamic exchange of gaseous elemental mercury during polar night and day, Atmos. Environ., 43, 5604 5610, doi:10.1016/j.atmosenv.2009.07.069, 2009.

Steen, A. O., Berg, T., Dastoor, A. P., Durnford, D. A., Engelsen, O., Hole, L. R., and Pfaffhuber, K. A.: Natural and anthropogenic atmospheric mercury in the European Arctic: a fractionation study, Atmos. Chem. Phys., 11, 6273-6284, doi:10.5194/acp-11-62732011, 2011. 
Steffen, A., Schroeder, W. H., Bottenheim, J., Narayan, J., and Fuentes, J. D.: Atmospheric mercury concentrations: measurements and profiles near snow and ice surfaces in the Canadian Arctic during Alert 2000, Atmos. Environ., 36, 2653-2661, 2002.

Steffen, A., Schroeder, W., Macdonald, R., Poissant, L., and Konoplev, A.: Mercury in the Arctic atmosphere: An analysis of eight years of measurements of GEM at Alert (Canada) and a comparison with observations at Amderma (Russia) and Kuujjuarapik (Canada), Sci. Total Environ., 342, 185-198, 2005.
Steffen, A., Douglas, T., Amyot, M., Ariya, P., Aspmo, K., Berg, T., Bottenheim, J., Brooks, S., Cobbett, F., Dastoor, A., Dommergue, A., Ebinghaus, R., Ferrari, C., Gardfeldt, K., Goodsite, M. E., Lean, D., Poulain, A. J., Scherz, C., Skov, H., Sommar, J., and Temme, C.: A synthesis of atmospheric mercury depletion event chemistry in the atmosphere and snow, Atmos. Chem. Phys., 8, 1445-1482, doi:10.5194/acp-8-1445-2008, 2008.

Tekran Inc.: Model 2537 A, Principles of Operation, Toronto, 1998. 